\title{
AN ANALYSIS OF CUSTOMER SHOPPING BEHAVIOR \\ IN AN OUT-OF-STOCK SITUATION: A CASE STUDY AT THE HYPERMARKET GIANT IN PURWAKARTA
}

\author{
Andre Maulana, Badikenita Sitepu \\ Swiss German University, Tangerang, Indonesia
}

\section{Article Information}

Received: 24 March 2020

Accepted: 29 May 2020

Published: 6 July 2020

DOI: $10.33555 / \mathrm{ijembm.v7i2.126}$

Corresponding Author:

Andre Maulana

Tangerang, Indonesia

Email: andre_maulana79@yahoo.com

ISSN $\quad 2338-8854$

eISSN 2620-9918

\begin{abstract}
Every retailers want to keep their customers from leaving the store. One of the conditions that can make customers leave the store is when they experience out of stock situation. Out of stock is a threat to all retailers, including in Giant Purwakarta. The existence of out of stock conditions can make consumers leave the store or stay in the store. The decision to stay or leave the store is influenced by the characteristics that the consumer have. This study examines how much influence of the customer's characteristic to the customer response when Giant Purwakarta out of stock. The type of this research is descriptive quantitative by using Pearson Chi-Square formula to analyse the relationship between variables. The results show that there are three characteristics that have significant value with customer response. The three characteristics are: general time constraint, brand loyalty, and store loyalty. On the other hand, the three characteristics of consumers found have no significant value with customer response when Giant Purwakarta facing out of stock. The three irrelevant characteristics are: Store distance, store price, and shopping trip. These results suggest that loyalty and time to shop become the most influential factors on consumer decision making to leave the store or stay in the store when retail store facing out of stock condition.
\end{abstract}

Keywords: Retail shop, Customer Behaviour, Out of Stock 


\section{Introduction}

Bitter competition in the Fast Moving Consumer Good (FMCG) industry has been present in many countries for much of the past century, including in Indonesia. The large number of population in Indonesia and their spending capability to consume goods are the main attraction for the market to make retail business, such as hypermarkets and supermarkets. Hypermarkets, supermarkets, and minimarkets continue to develop in Indonesia as purchasing power increases. The Indonesian retail sector began its rapid expansion in 1999, when a Presidential Decree (No. 96/2000 and 118/2000) allowed Carrefour, a French retailer, to expand retail operations in Jakarta. As other retailers followed, the Indonesian retail sector became more competitive, benefitting consumers and taking market share from traditional retail outlets. Foreign retailers in Indonesia include Carrefour (now locally owned and operated by CT Corp/PT Trans Retail, under the name Trans Mart), Giant, Lotte Mart (formerly Makro), Lion Superindo, Spar, Aeon, Circle K, Seven Eleven, Lawsons, Family Mart and Ministop.

Giant is one of the biggest retailer in Indonesia. Giant have stores in many location, include in Purwakarta. Giant Ekstra Purwakarta is one of 56 hypermarket stores that belong to PT.
Hero Supermarket Tbk. Open for public since 1st of January 2008. Located in Purwakarta regency, West Java. Giant Purwakarta have 2.781 sqm of trading area (sales floor), consist of 3 major divisions namely Grocery, GMS (Appliances, Bazaar, Textile) and Fresh. There are around 15.000 number of sku (product) available in their system to be served to the customer. In 2017, Sales growth in Giant Purwakarta drop signifycantly compare last year. One of the reasons due to out of stock situation. The top 1000 items which contribute $35 \%$ of sales have a shortage level above $15 \%$, which means potential lost sales above $5 \%$.

Over time, Purwakarta experienced a development that one of them in the field of retail. Currently, many retail stores in Purwakarta are adding competition with Giant Purwakarta. Within a $3 \mathrm{~km}$ radius (the optimal distance that consumers can buy to shop), there are 56 retail stores outside of Giant Purwakarta. The 56 retail stores are divided into: Alfa Minimarket (21 outlets), Alfa Midi (9 outlets), Indomaret (20 outlets), Yomart (4 outlets), TOKMA (1 outlet), and Yogya (1 outlet).

The large numbers of retail stores that are within a close radius make consumers have many options for shopping. This is a challenge for every retail store to avoiding out of stock situation. If they run out of stock consumers will leave the store and

Table 1. Indonesia Growths of Grocery Retail Sales and Outlets Number Source: Euromonitor, 2015

\begin{tabular}{lccccc}
\hline \multirow{1}{*}{ Type of Outlets } & \multicolumn{2}{c}{ Value of Growth } & $\begin{array}{c}\text { Number of } \\
\text { Outlets (,000) }\end{array}$ & \multicolumn{2}{c}{ No. Outlets Growth (\%) } \\
\cline { 2 - 3 } & 2013-2014 & $\begin{array}{c}\mathbf{2 0 0 9 - 2 0 1 4} \\
\text { (CAGR) }\end{array}$ & $\begin{array}{c}\mathbf{2 0 1 4} \\
\mathbf{2 0 1 3 - 2 0 1 4}\end{array}$ & $\begin{array}{c}\mathbf{2 0 0 9}-\mathbf{2 0 1 4} \\
\text { (CAGR) }\end{array}$ \\
\hline Convenience Stores & 19 & 34 & 22.8 & 13.6 & 17.8 \\
\hline Hypermarkets & 16.1 & 12.7 & 0.3 & 13.5 & 13.3 \\
\hline Supermarkets & 13.3 & 15 & 1.4 & 7.2 & 3.2 \\
\hline $\begin{array}{l}\text { Traditional Groceries } \\
\text { Retailers }\end{array}$ & 6.6 & 11.2 & $4,451.90$ & -1.7 & -0.6 \\
\hline
\end{tabular}


move to another store because of the many choices of stores. Out of Stock (OOS) or Stock out is a situation where the item is at a point of sale and is not available to the consumer in the store at the moment of purchase. A stockout is characterized by an inefficient process of refilling shelves (Vasconcellos \& Sampaio, 2009, p. 264). Thomas Gruen, Daniel Corsten \& Sundar Bharadwaj (2002) on his research showed a chart about worldwide consumer responses to Out of Stock (OOS). The chart state that $9 \%$ of consumer choose to not purchase the item if the retail store facing shortage. Then, $26 \%$ of consumers choose to choose the same product but with a different brand. There are also $19 \%$ of consumers who choose to buy different products for the same brand. Then, there are $31 \%$ of consumers who choose to leave the store and shop at another store. The rest, consumers choose to delay spending $(15 \%)$.

From this problem, researcher want to examine how big influence of consumer characteristic of Giant Purwakarta which is divided into six variables (store loyalty, general time constraint, brand loyalty, store price, store distance, and shopping trip) influence consumer behavior (leave the store, substitute Product, and delay purchase) when Giant Purwakarta facing out of stock situation.

\section{Literature Review}

To answer the research question above, the researcher uses a number of theories and concepts. The first theory is consumer behavior. Consumer behaviour is the study of the processes involved when individuals or group select, purchase, use, or dispose of products, services, ideas, or experiences to satisfy needs and desires (Solomon, 2007). Consumer behaviour involves the thought and feelings people experience and the actions they perform in consumption processes. It also includes all the things in the environment that influence these thoughts (Peter \& Olson, 2008).

Consumer behaviour on decision making has long been of interest to researchers. It began about 300 years ago; a group of economists, led by Nicholas Bernoulli, John Von Neumann and Oskar Morgenstern examine the basis of consumer decision making (Richarme, 2007). Since 1950's, the notion of consumer behaviour has responded to the conception and growth of modern marketing to encompass the more holistic range of activities that impact upon the consumer decision (Bray, 2008).

Second, is out of stock or stockout. A key problem in retail management was the fix

\section{Worldwide Consumer Responses to OOS}

(Average across eight categories)

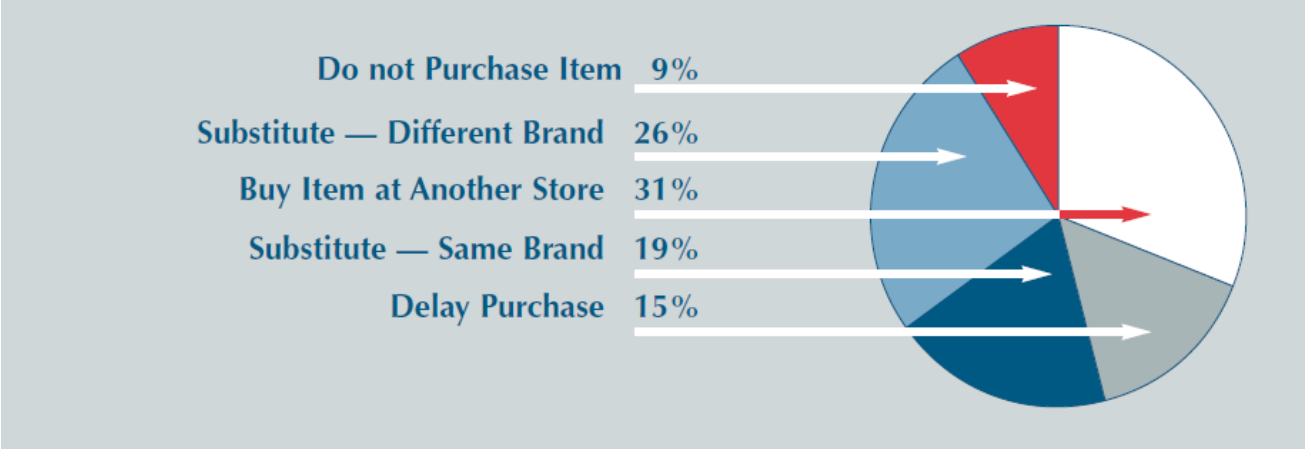

Figure 1. Worldwide Consumer Responses to OOS Source: Gruen, Corsten, \& Bahradwaj, 2002 
of adequate product variety, and perceived variety, through management of stock on hand. In managing this process, the retailer must strike a balance between over-stockings was that inventory management costs were higher, and risking stock outs that potentially result in lost sales and possible long term negative erect.

Practically, stock outs were an extremely important managerial problem. The prevalence in consumer settings had been well documented, as stock out levels of $10-30 \%$ have proven to be the norm, rather than the exception in many retail settings. In a recent study of a national supermarket chains Andersen Consulting (1996), 8.2\% of items were out-of-stock on an exemplary afternoon (this rate was more than $15 \%$ for advertised items). The stock out problem was worse in categories like bottled water $(10.7 \%)$ and chilled juice $(10.0 \%)$, and modify ranged nationwide from $8-10 \%$ for staple items as milk.

OOS condition thus made amount of loss on retail business. Corsten and Gruen (2003) on his research show that retail industries around the world facing losses about $3 \%-4 \%$ because out of stock. Figure 2 show the percentage of sales losses due to out of stock condition.

Gruen and his colleagues mentioned that consumer response related to out of stock condition there are some, such as: substitute product, delay purchase, and leave the store. This study uses the three consumer responses as the dimensions of the consumer behavior variable.

\section{Research Hypothesis}

The study sought to explore the general behavior of customers when an out-ofstock situation occurred at the Giant Hypermarket in Purwakarta, which was the objective of the study. In response of achieving the objective, based on the problem of how customers behaved when an out-of-stock situation occurred, the study had formulated at least six research questions that were expressed in terms of their null hypotheses at a significance level of 0.05. The following null hypotheses are expressed as follows:

\subsection{General Time Constraint}

General time constraint is the variable that looks at number of customer's visit to shop at Giant Purwakarta within one month.

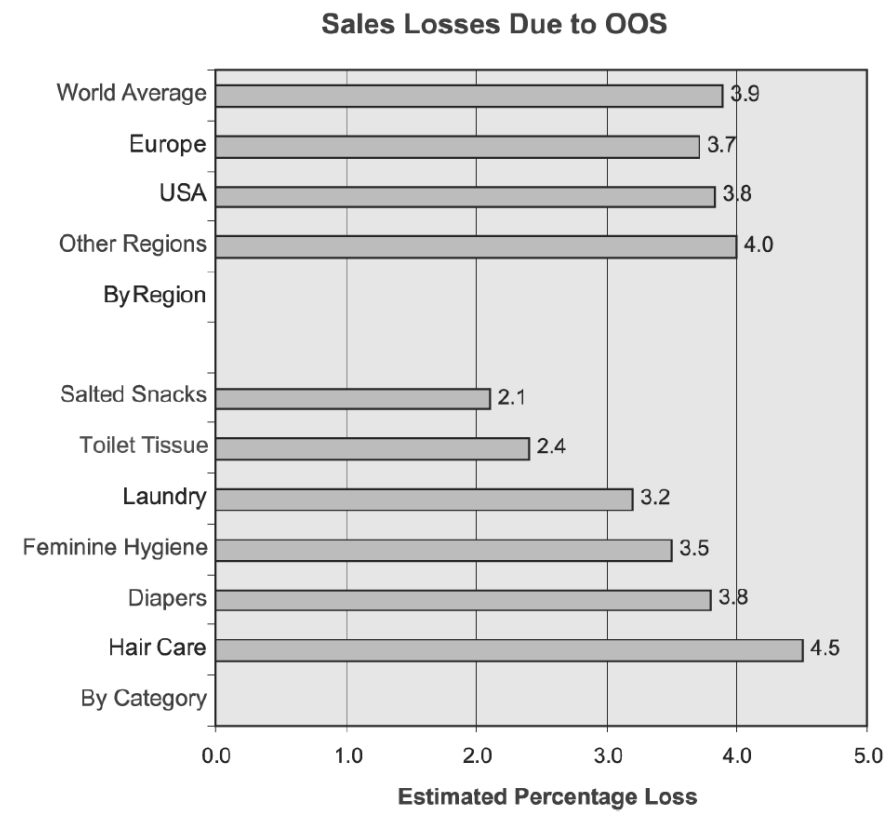

Figure 2. Sales Loses Due to OOS Source: Gruen \&Corsten, 2003, p. 608 
H1: General Time Constraint didn't have a significant relationship with customer response in out of stock situation.

\subsection{Store Loyalty}

Store loyalty variable focus on how long customers have been shopping at Giant Purwakarta.

$\mathrm{H} 2$ : Store Loyalty didn't have a significant relationship with customer response in out of stock situation.

\subsection{Store Price}

Store price variable talks about customer's perception on item price in Giant Purwakarta.

H3: Store Price didn't have a significant relationship with customer response in out of stock situation.

\subsection{Brand Loyalty}

Brand Loyalty is the variable that focuses on how long customers have used a product with a particular brand.

H4: Brand Loyalty didn't have a significant relationship with customer response in out of stock situation.

\subsection{Shopping Trip}

Shopping trip is average time spent by customer when shopping in Giant Purwakarta.

H5: Shopping Trip didn't have a significant relationship with customer response in out of stock situation

\subsection{Store Distance}

Store distance is the required travel time from customer's home to Giant Purwakarta.

H6: Store Distance didn't have a significant relationship with customer response in out of stock situation

\section{Methodology}

\subsection{Type of Research}

Related to research methodology, this research is quantitative descriptive type. That is a research approach with large amount of data summing method and numerical by using statistical formulas (Ruane, 2013, p.19).

\subsection{Sampling Technique and Data Collection}

Basically there were two types of data collection. Primary data collected through surveys based on quantitative data. Secondary data collected from documentary study, such as collected data from previous study.

\subsection{Sample Size}

Sample size was 397 respondents.

\subsection{Instrument of Data Collection}

The instrument was in the form of closed questions. Respondents were asked about seven primary questions. In addition to collecting data, there were two open questions that asking the items that consumer's bought and the reason why consumer choose one of the response when Giant Purwakarta facing out of stock condition.

\subsection{Research Model Developed}

The study focused on customer's response related to out of stock condition. Product limitation was that researcher only looked and emphasize on the low priced consumables, such us detergent, soap, toothpaste, etc, which had faced frequent stock outs and the results were not generalized therefore the different product classes which have different characteristics as consumer can react in a different manner. 


\subsection{Statistical Technique}

Descriptive and inferential statistical analysis will be applied on the data gathered. In order to do a hypothesis testing, this research using Pearson Chi Square Formula. Pearson's chi-squared test $\left(\chi^{2}\right)$ is used to determine if there is a significant relationship between two nominal (categorical) variables.

\section{Result}

The research data collected through a questionnaire based survey with closed question. The respondents were limited only for customer which shop on Giant Purwakarta on last six months. Total respondent were 397 customers. For the pre-test questionnaire, there were 40 respondents.

\subsection{Validity and Reliability Test}

Validity test assure us to be reasonably certain that the question in questionnaire is valid. In this research, Pearson Correlation Coefficient was used as the tool to check the validity of the question asked. Beside validity test, there are

reliability test. Reliability test is used to measure the consistency of the measurement across time and across the various items in the instrument.

To make sure the question is valid; the correlation coefficient value of the question must be above the correlation coefficient value from Pearson Table. In this research, the correlation coefficient value of the questions should above 0.304 for significant level is 5\%. And for reliability test on this research using testretest method. Test-Retest reliability measures consistency of the questionnaire instruments. In this research, SPSS for Windows Ver.19 used Cronbach's Alpha to examine reliability by determining the internal consistency of a test. If the alpha is greater than or same as 0.60 , then the variable is reliable (see table 3 ). If alpha is smaller than 0.60 , then the variable is not variable.

The table 2 shows the result of validity test of this research.

Table 2. Validity Test Summary Result

\begin{tabular}{ccccc}
\hline \multirow{2}{*}{ NO } & \multirow{2}{*}{ QUESTION CODE } & \multicolumn{2}{c}{ CORRELATION } & \multirow{2}{*}{ INTERPRETATION } \\
\cline { 2 - 4 } & & TEST & RETEST & \\
\hline 1 & SLQ & 889 & 889 & VALID \\
\hline 2 & SPQ & 562 & 562 & VALID \\
\hline 3 & SDQ1 & 614 & 651 & VALID \\
\hline 4 & SDQ2 & 537 & 183 & INVALID \\
\hline 5 & TCQ & 889 & 889 & VALID \\
\hline 6 & STQ & 466 & 466 & VALID \\
\hline 7 & BLQ & 655 & 655 & VALID \\
\hline 8 & CRQ & 922 & 922 & VALID \\
\hline
\end{tabular}

From Table 2 above, one question has correlation value less than 304 . In order to have a valid instrument, SDQ2 question should be erased from the model. If SDQ2 and SDQ2x erased, the cronbach's alpha value changed to 0.924 . 
Table 3 shows the summary of reliability test result after SDQ2 not submitted on questionnaire. All dimensions used in this research provided acceptable and reliable (above 0.60).

Table 3. Result of Reliability Test

\begin{tabular}{cccc}
\hline VARIABLES & CRONBACH'S ALPHA & N OF & INTERPRETATION \\
& & 2 & Excellent \\
\hline Store Loyalty & 0,925 & 2 & Acceptable \\
\hline Store Price & 0,661 & 2 & Excellent \\
\hline Store Distance & 0,924 & 2 & Excellent \\
\hline General Time Constraint & 0,939 & 2 & Acceptable \\
\hline Shopping Trip & 0,631 & 2 & Adequate \\
\hline Brand Loyalty & 0,786 & 2 & Excellent \\
\hline Customer Response & 0,959 & & \\
\hline
\end{tabular}

\section{Analysis}

Researchers conducted data collection by distributing questionnaires of 397 copies. The questionnaire contained seven multiple-choice questions. Questionnaires were distributed to customers of Giant Purwakarta to be answered by them. A total of 397 questionnaires are returned completely and also all the questions had been answered completely.

Table 4. Summary of Data Collection

\begin{tabular}{lrrrrrrr}
\hline & \multicolumn{9}{c}{ Cases } \\
\cline { 2 - 7 } & \multicolumn{2}{c}{ Valid } & \multicolumn{2}{c}{ Missing } & \multicolumn{2}{c}{ Total } \\
\cline { 2 - 8 } & $\mathrm{N}$ & Percent & $\mathrm{N}$ & Percent & $\mathrm{N}$ & Percent \\
\hline SLQ * CRQ & 397 & $100.0 \%$ & 0 & $.0 \%$ & 397 & $100.0 \%$ \\
SPQ * CRQ & 397 & $100.0 \%$ & 0 & $.0 \%$ & 397 & $100.0 \%$ \\
SDQ * CRQ & 397 & $100.0 \%$ & 0 & $.0 \%$ & 397 & $100.0 \%$ \\
STQ * CRQ & 397 & $100.0 \%$ & 0 & $.0 \%$ & 397 & $100.0 \%$ \\
TCQ * CRQ & 397 & $100.0 \%$ & 0 & $.0 \%$ & 397 & $100.0 \%$ \\
BLQ * CRQ & 397 & $100.0 \%$ & 0 & $.0 \%$ & 397 & $100.0 \%$ \\
\hline
\end{tabular}

The collected data processed using Pearson Chi-Square formula. The term "chi-square" refers both to a statistical distribution and to a hypothesis testing procedure that produces a distributed as the chi-square distribution (Howell, 2011). The basis of decision making in chi square test can be done by looking at the
Asymp. Sig value of Chi-Square Test.

i. If the Chi Square counts > Chi Square table, then there is a significant relationship between row and column

ii. If Chi Square counts < Chi Square table, then there is no significant relationship between row and column 


\subsection{General Time Constraint Hypothesis and Interpretation}

The table 5 shows the time constraint and customer response cross tabulation. The table 6 shows Chi-Square Test of general time constraint variable.

Based on data processing, for variable General Time Constraint $\mathrm{H} 1$ accepted, that is "General Time Constraint did have a significant relationship with customer response in out of stock situation". This results indicate that lower time constraint that customer have then fewer customer choose to leave the store when Giant Purwakarta out of stock.
This interpretation is derived from Table 5 which indicates a decrease in the number of customers who choose to leave the store when they have more time to shop.

Customers who choose to stay in store when experience out of stock at Giant Purwakarta can also due to atmospheric or a comfortable atmosphere to shop at Giant Purwakarta. Atmospheric is the process of creating various consumer effects (Solomon, et al., 2006, p. 323). The dimensions include sensory dimensions, such as: sound, color, and aroma. The entertainment strategy like a kid's zone is one of the most successful atmospheric strategies in the Giant stores.

Table 5. Time Constraint and Customer Response Cross Tabulation

\begin{tabular}{llcccc}
\hline & & \multicolumn{3}{c}{ CRQ } & \\
\cline { 3 - 5 } & & $\begin{array}{c}\text { Substitute } \\
\text { Product }\end{array}$ & $\begin{array}{c}\text { Delay } \\
\text { Purchase }\end{array}$ & Leave Store & Total \\
\hline \multirow{2}{*}{ TCQ } & Very High Time Constraint & $22 \%$ & $24 \%$ & $54 \%$ & $17 \%$ \\
& High Time Constraint & $23 \%$ & $26 \%$ & $51 \%$ & $23 \%$ \\
& Average Time Constraint & $22 \%$ & $32 \%$ & $46 \%$ & $32 \%$ \\
& Low Time Constraint & $35 \%$ & $26 \%$ & $39 \%$ & $28 \%$ \\
\multirow{2}{*}{ Total } & & $28 \%$ & $26 \%$ & $46 \%$ & $100 \%$ \\
\hline
\end{tabular}

Table 6. Chi-Square Test of General Time Constraint Variable

\begin{tabular}{lcrrr}
\hline & & & $\begin{array}{c}\text { Asymp. Sig. } \\
(2-\text {-sided })\end{array}$ \\
\hline Pearson Chi-Square & 20,056 & & 6 &, 003 \\
\hline
\end{tabular}




\subsection{Store Loyalty Hypothesis and Interpretation}

The table 7 shows store loyalty and customer response cross tabulation. The table 8 shows Chi-Square Test of store loyalty variable.

Based on data processing, for variable Store Loyalty H1 accepted, that is "Store Loyalty did have a significant relationship with customer response in out of stock situation". Significant relationship here can be interpreted that the higher store loyalty of Giant Purwakarta's customers, the fewer they are to choose leave the store when experience out of stock in those store. This is consistent with the view that store's loyal customers are less likely to switch to another store in the case of an out of stock occurrence (Campo, Gijsbrechts, \& Nisol, 2003).

Customers decision to stay in the store majority driven by the situation that they do monthly expenditure for household need in Giant Purwakarta and reluctant to find or shop in other store. Here, it appears that Giant Purwakarta which provides complete assortments drives customers to do one-stop shopping while doing purchase there. That is, there are so many things to look for, and when there are one or two item were out of stock, they will stay in the store and shop for other items that are available or more urgent items.

Table 7. Store Loyalty and Customer Response Cross Tabulation

\begin{tabular}{llcccr}
\hline & & \multicolumn{3}{c}{ CRQ } & \\
\cline { 3 - 5 } & & $\begin{array}{c}\text { Substitute } \\
\text { Product }\end{array}$ & $\begin{array}{c}\text { Delay } \\
\text { Purchase }\end{array}$ & Leave Store & Total \\
\hline \multirow{2}{*}{ SLQ } & Low Store Loyalty & $7 \%$ & $21 \%$ & $72 \%$ & $3 \%$ \\
& Average Store Loyalty & $0 \%$ & $47 \%$ & $53 \%$ & $4 \%$ \\
& High Store Loyalty & $29 \%$ & $24 \%$ & $47 \%$ & $15 \%$ \\
& Very High Store Loyalty & $30 \%$ & $26 \%$ & $44 \%$ & $78 \%$ \\
Total & & $28 \%$ & $26 \%$ & $46 \%$ & $100 \%$ \\
\hline
\end{tabular}

Table 8. Chi-Square Test of Store Loyalty Variable

\begin{tabular}{lcrrr}
\hline & Value & Df & \multicolumn{2}{c}{$\begin{array}{c}\text { Asymp. Sig. } \\
\text { (2-sided) }\end{array}$} \\
\hline Pearson Chi-Square & 12,970 & & 6 &, 044 \\
\hline
\end{tabular}




\subsection{Store Price Hypothesis and Interpre- tation}

The table 9 shows store price and customer response cross tabulation. The table 10 shows Chi-Square Test of store price variable.

From the data processing using ChiSquare test, Asymp. Sig obtained is 0.599 . These results indicate that Asymp. Sig related store loyalty greater than critical value, that is 0,05 . In other words, there is no significant relationship between store price and consumer response related to out of stock situation. Thus, for variable Store
Price H0 accepted, that is "Store Price didn't have significant relationship with customer response in out of stock situation".

This result is similar to that of Chisty Loya and colleagues who also found that perceived store prices didn't have have any impact on consumers response. They say that the lack of impact may also depend on the type of product category and store atmosphere (Chisty, et al., 2015, p.185). This indicates that there are other variables that are more influential on the consumer besides the price offered, such as product availability time for shopping and loyalty to the store.

Table 9. Store Price and Customer Response Cross Tabulation

\begin{tabular}{lcrrrr}
\hline & & \multicolumn{3}{c}{ CRQ } & \\
\cline { 3 - 5 } & & $\begin{array}{c}\text { Substitute } \\
\text { Product }\end{array}$ & $\begin{array}{c}\text { Delay } \\
\text { Purchase }\end{array}$ & Leave Store & Total \\
\hline SPQ & High Price & $23 \%$ & $25 \%$ & $52 \%$ & $13 \%$ \\
& Low Price & $29 \%$ & $26 \%$ & $45 \%$ & $87 \%$ \\
\multirow{2}{*}{ Total } & $28 \%$ & $26 \%$ & $46 \%$ & $100 \%$ \\
\hline
\end{tabular}

Table 10. Chi-Square Test of Store Price Variable

\begin{tabular}{lcrr}
\hline & Value & Df & $\begin{array}{c}\text { Asymp. Sig. } \\
\text { (2-sided) }\end{array}$ \\
\hline Pearson Chi-Square & 1,025 & & 2 \\
\hline
\end{tabular}




\subsection{Brand Loyalty Hypothesis and Inter- pretation}

The table 11 shows brand loyalty and customer response cross tabulation. The table 12 shows Chi-Square Test of brand loyalty variable.

From the data processing using ChiSquare test, Asymp. Sig obtained is 0.000. These results indicate that Asymp. Sig related Brand Loyalty less than critical value, that is 0,05 . In other words, there is a significant relationship between brand loyalty and consumer response related out of stock situation. Based on data processing, for variable Brand Loyalty H1 accepted, that is "Based on data processing, for variable Brand Loyalty H1 accepted, that is "Brand Loyalty did have a significant relationship with customer response in out of stock situation".
The data below can be interpreted that the higher their brand loyalty, the more customers decide to delay purchase. It can be understood that customers already believe in the quality of the products issued by a brand, so when the stock in store is not available, they choose to delay purchase. This is supported also by the position that the product they are looking for is not very needed in the short time.

The data also show that the higher customer loyalty to a brand, the more likely they delay purchase when the brand they are looking for at Giant Purwakarta are not available. This result in line to what Campo and colleagues (2003) have said, that the more loyal a customer is to a specific brand, the less likely he or she is to switch to a different brand in the case of an out of stock occurrence.

Table 11. Brand Loyalty and Customer Response Cross Tabulation

\begin{tabular}{llrrrr}
\hline & & \multicolumn{3}{c}{ CRQ } & \\
\cline { 3 - 5 } & & $\begin{array}{c}\text { Substitute } \\
\text { Product }\end{array}$ & $\begin{array}{c}\text { Delay } \\
\text { Purchase }\end{array}$ & Leave Store & Total \\
\hline BLQ & Low Brand Loyalty & $21 \%$ & $17 \%$ & $62 \%$ & $15 \%$ \\
& Average Brand Loyalty & $24 \%$ & $20 \%$ & $56 \%$ & $57 \%$ \\
& High Brand Loyalty & $43 \%$ & $39 \%$ & $18 \%$ & $17 \%$ \\
& Very High Brand & $33 \%$ & $50 \%$ & $17 \%$ & $11 \%$ \\
& Loyalty & & & & \\
Total & & $28 \%$ & $26 \%$ & $46 \%$ & $100 \%$ \\
\hline
\end{tabular}

Table 12. Chi-Square Test of Brand Loyalty Variable

\begin{tabular}{lcrrr}
\hline & Value & Df & $\begin{array}{c}\text { Asymp. Sig. } \\
(2 \text {-sided })\end{array}$ \\
\hline Pearson Chi-Square & 55.037 & & 6 & .000 \\
\hline
\end{tabular}




\subsection{Shopping Trip Hypothesis and Inter- pretation}

The table 13 shows shopping trip and customer response cross tabulation. The table 14 shows Chi-Square Test of shopping trip variable.

From the data processing using ChiSquare test, Asymp. Sig obtained is 0.310. These results indicate that Asymp. Sig related to Shopping Trip is bigger than critical value, that is 0,05 . In other words, there is no significant relationship between shopping trip with consumer response related to out of stock situation. Based on data processing, for variable Shopping Trip H0 accepted, that is "Shopping Trip did have a no significant relationship with customer response in out of stock situation".
Based on table 14, it appears that there is no specific pattern of customer response regarding out of stock situation in Giant Purwakarta according to their shopping trip. Although they do shopping trip more and more, there is no increase or decrease in structured from each choice. This shows that there is no significance between shopping trip customers and their responses.

This data shows that there is no great influence on how many times a customer can shop within a month with their response when experience out of stock in Giant Purwakarta. Time that customers have in one shopping activity (general time constraint variable) is more influential than the frequent of shopping. That is, Customer in Giant Purwakarta tries to meet all their needs within one shopping and that is where the right response should be chosen by them.

Table 13. Shopping Trip and Customer Response Cross Tabulation

\begin{tabular}{llrccr}
\hline & & \multicolumn{3}{c}{ CRQ } & \\
\cline { 3 - 5 } & & $\begin{array}{c}\text { Substitute } \\
\text { Product }\end{array}$ & $\begin{array}{c}\text { Delay } \\
\text { Purchase }\end{array}$ & Leave Store & Total \\
\hline TCQ & Low Shopping Trip & $25 \%$ & $22 \%$ & $53 \%$ & $30 \%$ \\
& Average Shopping Trip & $26 \%$ & $28 \%$ & $46 \%$ & $47 \%$ \\
& High Shopping Trip & $37 \%$ & $28 \%$ & $35 \%$ & $17 \%$ \\
& Very High Shopping Trip & $35 \%$ & $26 \%$ & $39 \%$ & $6 \%$ \\
Total & & $28 \%$ & $26 \%$ & $46 \%$ & $100 \%$ \\
\hline
\end{tabular}

Table 14. Chi-Square Test of Shopping Trip Variable

\begin{tabular}{lccrr}
\hline & Value & Df & \multicolumn{2}{c}{$\begin{array}{c}\text { Asymp. Sig. } \\
\text { (2-sided) }\end{array}$} \\
\hline Pearson Chi-Square & 7.121 & & 6 & .310 \\
\hline
\end{tabular}




\subsection{Store Distance Hypothesis and Inter- pretation}

The table 15 shows store distance and customer response cross tabulation. The table 16 shows Chi-Square Test of store distance variable.

From the data processing using ChiSquare test, The obtained Asymp. Sig is 0.191. These results indicate that Asymp. Sig related Store Distance is greater than the critical value, that is 0,05 . In other words, there is no significant relationship between store distance and consumer response related to out of stock situation.

Based on data processing, for variable Store Distance H0 accepted, that is "Store
Distance didn't have a significant relationship with customer response in out of stock situation".

Although table 15 shows the existence of a relation, but this relation is irrelevant. Because the closer the customer's residence to the Giant Purwakarta store, the more likely it is for them to delay their purchase. The proximity of the distance between the house and the store makes them easy to reach the store and thus easily get the items they are looking for when the stock is available. The above data precisely shows the consumer class with a far distance home that prefer to delay purchase.

Table 15. Store Distance and Customer Response Cross Tabulation

\begin{tabular}{llrrrr}
\hline & & \multicolumn{3}{c}{ CRQ } & \\
\cline { 3 - 5 } & & $\begin{array}{c}\text { Substitute } \\
\text { Product }\end{array}$ & $\begin{array}{c}\text { Delay } \\
\text { Purchase }\end{array}$ & Leave Store & Total \\
\hline SDQ & Far & $28 \%$ & $31 \%$ & $41 \%$ & $10 \%$ \\
& Far Enough & $19 \%$ & $29 \%$ & $52 \%$ & $30 \%$ \\
& Close Enough & $32 \%$ & $25 \%$ & $43 \%$ & $55 \%$ \\
& Near & $42 \%$ & $16 \%$ & $42 \%$ & $5 \%$ \\
Total & & $28 \%$ & $26 \%$ & $46 \%$ & $100 \%$ \\
\hline
\end{tabular}

Table 16. Chi-Square Test of Store Distance Variable

\begin{tabular}{lcrrr}
\hline & Value & Df & \multicolumn{2}{c}{$\begin{array}{c}\text { Asymp. Sig. } \\
\text { (2-sided) }\end{array}$} \\
\hline Pearson Chi-Square & 8.699 & 6 & .191 \\
\hline
\end{tabular}




\subsection{Hypothesis Summary}

Researchers have done the analysis and interpretation of the data in the previous section and have obtained data related to the hypothesis of this study received and rejected. Table 17 summarize all the hypothesis proposed in this research. Conclusion will be made based on below result.

Table 17. Hypothesis Summary

\begin{tabular}{llcc}
\hline NO & \multicolumn{1}{c}{ HYPOTHESIS } & SIG.VALUE & RESULT \\
\hline 1 & $\begin{array}{l}\text { H1: General Time Constraint has a significant } \\
\text { relationship with customer response in out of stock } \\
\text { situation. }\end{array}$ & Rejected \\
\hline 2 & $\begin{array}{l}\text { H2: } \text { Store Loyalty has a significant relationship with } \\
\text { customer response in out of stock situation. }\end{array}$ &, 044 & Rejected \\
\hline 3 & $\begin{array}{l}\text { H3: Store price has a significant relationship with } \\
\text { customer response in out of stock situation. }\end{array}$ &, 599 & Accepted \\
\hline 4 & $\begin{array}{l}\text { H4: Brand loyalty has a significant relationship with } \\
\text { customer response in out of stock situation. }\end{array}$ &, 000 & Rejected \\
\hline 5 & $\begin{array}{l}\text { H5: Shopping trip has a significant relationship with } \\
\text { customer response in out of stock situation. }\end{array}$ &, 310 & Accepted \\
\hline 6 & $\begin{array}{l}\text { H6: Store distance has a significant relationship with } \\
\text { customer response in out of stock situation. }\end{array}$ &, 191 & Accepted \\
\hline
\end{tabular}

\subsection{Discussion}

Majority of customers choose to leave the store when Giant Purwakarta out of stock situation. The distribution result from 397 questionnaires, $182(46 \%)$ consumers answered leaving the store, then 111 $(28 \%)$ consumers answered the substitute product, and another 104 (26\%) choose to delay purchase.

The tendency of consumers to leave the store can be influenced by many factors. Not only the factors that exist in the six variables of consumer characteristics, but there are external factors that allow consumers to prefer leave the store. One of the most powerful factors is the presence of so many other stores (competitors) in the Purwakarta area. As explained earlier in this study, Indonesia is opening a great opportunity for investors to set up grocery retail stores, so that many stores can be built and thus the competition between stores can be more intense. However, further research is needed to confirm this assumption.
Loyalty becomes an important thing to note. Viewed from the significant value, the most influential consumer characteristics to the selection of their response when Giant Purwakarta out of stock condition is brand loyalty (sig. Value $=, 000$ ). After brand loyalty, the second characteristic of influence is the general time constraint (sig. value $=$ ,003). And the third characteristic is store loyalty (sig. value $=, 044$ ). Based on this data, it appears that customers at Giant Purwakarta are heavily influenced by their loyalty and the availability of time when they do the shopping activity.

This conclusion is also supported by the culture of citizens in Indonesia who tend to have "langganan" (subscription) stores and products. Consumers in Indonesia tend to shop in the same place and look for items with the same brand for years when it seems that the store subscribes to provide all their needs, including goods with certain brands that also become subscribers. Therefore, it needs to be a 
concern for retail store owners to be able to keep store loyalty from the consumer, so they do not leave the store when the goods with the brand that they are looking for are in out of stock situation.

\section{Conclusion and Recommendation}

Based on the analysis done in the previous chapter, there are several points of conclusion that can be described in order to answer the research question in this work:

a. There is a significant relationship between general time constraint and the customer response when customer facing out of stock situation in Giant Purwakarta.

b. There is a significant relationship between store loyalty and the customer response when customer facing out of stock situation in Giant Purwakarta.

c. There is a significant relationship between brand loyalty and the customer response when customer facing out of stock situation in Giant Purwakarta.

d. Statistically, perceive store price has no significant relationship with customer response in out of stock situation.

e. Shopping trip has no significant relationship with customer response in out of stock situation.

f. Even though from frequency distribution table exist a pattern show that the closer of store distance to customer premises the more likely they delay the purchase.
Thus, the following is a recommendation to the Giant Purwakarta related research results and from another store business in Indonesia. In addition, researchers are aware that the research is still a lot of shortcomings. Therefore, there are recommendations related to further research that can support this research:

a. For Giant Purwakarta:

i. Regular checking of stock of goods in shelf

ii. Conducting a consumer market survey of Giant Purwakarta about what items are needed but often experience out of stock condition.

iii. Negotiate with product / brand producers so Giant Purwakarta gets priority (improving service level) for distribution of goods most sought after by Giant consumers but often out of stock.

b. For Every Store Business: Loyalty to the store has an important role in customer decision. So, all retailers have to do extra efforts to improve their customer store loyalty.

c. For Further Research:

i. The need for research on external factors outside the consumer to support this research.

ii. In addition to external factors and characteristics that exist in customer's side, it is also necessary to focus on the other variables that exist in the Giant Purwakarta's store. 


\section{References}

Bray, J. P. (2008). Consumer behavior theory: approaches and models. Bournemouth: Bournemouth University. Discussion Paper.

Campo, K., Gijsbrechts, E., \& Nisol, P. (2003). The impact of retailer stockouts on whether, how much, and what to buy. International Journal of Research in Marketing, 20(3), 273-286.

Chisty, L. (2015). Consumer response in out of stock situation at a retail store. International Journal of Humanities and Social Science, 5(3).

Corsten, D. \& Gruen, T. (2003). Desperately seeking shelf availability: an examination of the extene, the causes, and the efforts to address retail out-of-stocks. International Journal of Retail \& Distribution Management, 31(12), 605-617.

Gruen, T., Corsten, D \& Bharadwaj, S. (2002). Retail out of stocks: a worldwide examination of extent, causes and consumer responses. Washington DC: Grocery Manufacturers of America.

Peter, J. P., Olson, J. C. (2008). Consumer behavior \& marketing strategy, 8th Ed. New York: McGraw Hill.

Richarme, M. (2007). Consumer decisionmaking models, strategies, and theories. www.decisionanalyst.com /downloads/consumerdecisionmaki ng.pdf. 15 May 2017.

Ruane, J. M. (2013). Metode penelitian: panduan riset ilmu sosial. Bandung: Nusamedia.
Solomon, Michael R. (2007). Consumer behavior: buying, having and being, 7th Ed. New Jersey: Pearson Prentice Hall.

Solomon, M., Bamossy, G, Askegaard, S \& Hogg, M. K. (2006). Consumer behaviour: a European perspective. 3rd ed. England: Pearson Education Limited.

Vasconcellos, L. H. R. \& Sampaio, M. (2009). The stockouts study: an examination of the extent and the causes in the Sao Paulo supermarket sector. Brazilian Administration Review, Curitiba, 6(3), 263-279. 